\title{
Environmental Law Science and Its Novelty in the Field of Problem-solving Research
}

\author{
Elena Grishnova \\ National Research University \\ Bauman Moscow State Technical University \\ 5/1 2d Baumanskaya Street \\ Moscow, Russia 105005 \\ E-mail: grishnovaiip@yandex.ru
}

\author{
Sergey Zhdanov \\ Russian Customs Academy \\ 4 Komsomolsky Prospect \\ Lyubertsy, Russia 140015 \\ E-mail: zhdanov120009@yandex.ru
}

\begin{abstract}
The article considers new factors of modern legal reality which form a social demand to activate practiceoriented studies of this reality, which are of fundamental nature. There is the analysis of the state of environmental law science and its novelty in the field of problem research through the prism of the indicated approach, based on the recently defended doctoral dissertations (Gizatullin R.Kh. "Ecological function of the state: theory and practice of implementation", Buchakova M.A. "Coordination in the system of state and municipal management of environmental protection of the Russian Federation", Vykhanova G.V. "Legal problems of information support of using nature and environmental protection", Vershilo N.D. "Ecological law basis for sustainable development", Misnik G.A. "Compensation of environmental harm in Russian law"). In the final part conclusions are drawn and suggestions are made.
\end{abstract}

Keywords-globalization; global transformation; approbation; science; practice; ecology; ecological law; scientific novelty

\section{INTRODUCTION}

The global transformation that humanity is experiencing today is obvious to the scientific community. It can be characterized, from our point of view, as a period of extreme turbulence in an era of maximum uncertainty. There are nonlinear global changes in the whole structure of modern society, which is defined by the term "globalization". The optimistic expectations of the inevitable development and prosperity for all as the consequences of globalization are a thing of the past.

The world scientific community again comes back to the growing danger of self-destruction of mankind as a result of this transformation, which can lead to the collapse of the fragile stability of the world system as a result of any of the global catastrophes (military, economic, geopolitical, nuclear, ecological, food, demographic and etc.).

The real collision of two differently directed tendencies of globalization does not add stability to the world: 1) the tendency of the unification of the world community, the concentration of economic, financial, political and military power in the hands of a small group of countries led by the United States and the determination of their global goals by the logic of their own (and because of this) limited socioeconomic and geopolitical interests (today the exclusive interests of one country - the US "America first" - the policy slogan of Donald Trump), defined mainly in line with the prospect of the development of their own civilizations; 2) the tendency of the segmentation of the world, the growth of the aspirations of its individual elements to national-cultural, civilizational self-identification [1]. The necessity of living in a "single humanity" co-exists with a desire for sociopolitical, cultural isolation, national-cultural and political separatism [2].

If the first trend was dominant in the 80 s and 90s, today the situation has changed and the second has become the defining one. The solution of environmental problems is drawn into the orbit of the global multidirectional transformation. Ecology is a phenomenon of a special kind, characterized by the fact that even a small force impact on it can lead to unpredictable consequences for all mankind. We are not talking about the goal-oriented aspiration of the "global leader" (USA) to completely "reformat" the existing global approaches to environmental problems in the interests of the "selected" part of the world community. In particular, the president of the most powerful economy in the world of the United States of America Donald Trump has already announced the withdrawal from the 2015 Paris Agreement on climate. The argument is very indicative: it does not meet the interests of American companies and the whole of American industry, the withdrawal from the agreement corresponds to the chosen policy "America is above all".

In this situation, global problems (including environmental ones) cease to be the main ones, the dominant ones. They go into the background and acquire a "service" character for the US economy.

In fact, the country, the leader of globalization, announces the need to "reformat" the existing world legal model for solving global problems, about its reorientation to serve the interests of one country - the US. In this context, law is viewed as an instrument of the global power of the United States of America.

Russia has already "gone through" such situations and has a negative experience with the application of this 
approach. For several decades of the twentieth century in the USSR, law was viewed in a similar way - as an instrument, a lever of power, as a way of legalizing political decisions of a party, and not as an independent social and cultural substance. The law for a long time was considered, on the one hand, as the set of various necessary fixed formal norms, and, on the other hand, it was used as a means of violence, compulsion to please the authorities. These two hypostases of law co-existed within the framework of one legal and political system, when the punitive function coexisted with the "educational" one. Therefore, the leaders of the Soviet state looked at the concept of law as both a kind of rudiment, a hindrance, and as a convenient, "legal" political tool, a repressive mechanism in the fight against political opponents. The law was not conceived as a force capable of limiting the power of state; and the idea of a law-based state was not recognized. In this context, the law was completely subordinated to a policy which was highly ideological in nature and often did not take into account the importance of a real solution of environmental and other problems [3] [4].

\section{ANALYSIS OF CURRENT FUNDAMENTAL STUDIES IN ENVIRONMENTAL LAW IN RUSSIA}

In his introduction to the 22nd edition of the textbook on the Environmental Law of Russia, the leading Russian scientist in the field of environmental and land law, the publisher of the first in Russia textbook on environmental law, which has withstood repeated reprints, Academician of the Russian Ecological Academy B.V. Erofeev noted: "Everything is interconnected with everything - says the first environmental law. Hence, the step cannot be stepped, without hitting, and sometimes not breaking anything from the environment. Each step of a man on an ordinary lawn is a dozen ruined microorganisms, frightened off insects, which change migration routes, and may reduce their natural productivity. Therefore, the thoughtless behavior of a person in natural ecosystems resembles the behavior of an elephant in a china shop with the only difference that broken dishes can be replaced by new ones, and the destroyed natural objects and ecological interrelations between them are irreversibly violated. Already in the last century there was a man's concern for the fate of the planet, and in the current century it came to the crisis of the world ecological system because of anthropogenic increase of pressure on the environment" [5].

Russia is among the countries where significant problems with the environment remain. Although there has been a general positive trend in recent years, but it is proceeding at a slow pace or not at all. This trend is recorded in the report of the Organization for Economic Cooperation and Development (OECD) "Green Growth Indicators 2017". It is proved there that the level of emissions of harmful substances in Russia is much higher than in many large countries of the world, which leads to increased risks for the population. Russia was in the second place out of 46 countries in terms of the number of deaths from contamination with suspended particles of PM2.5 and ozone (O3) per 1 million people of the population in 2015. According to the OECD, the Russian Federation ranks first in terms of emissions of sulfur dioxide ( $\mathrm{SO} 2)$ per $\$ 1$ of Purchasing power parity (PPP) of Gross domestic product (GDP) (data of 2016), hydrocarbon oxide (CO) emissions per \$ 1 of PPP of GDP. Emissions of sulfur dioxide are 16.6 times higher than in France, 10.5 times higher than in Germany, and 4.2 times higher than in the USA. We are also ahead of Germany in CO emissions 5.3 times, France 3.5 times, and the USA 1.5 times. A very similar situation, according to analysts, is also taking shape for other types of harmful emissions [11].

According to the Ministry of Natural Resources, which in 2017 published a report on the implementation and evaluation of the effectiveness of the state program "Environmental Protection for 2012-2020" for 2016, the target values of a significant number of benchmarks were not realized. So, in terms of "the volume of emissions of air pollutants from stationary sources in the fuel and energy complex in percentage to 2007" in 2016 these pollutants amounted to $80.3 \%$ of the level of 2007 with the planned target of 71.4; concerning the indicator "the volume of emissions of air pollutants from stationary sources in metallurgy in percentage to 2007" in 2016 these pollutants amounted to $80.5 \%$ of the level of 2007 , with the target value of 71.7 planned in the program, regarding "the volume of emissions of air pollutants from road transport in percentage to 2007 " in 2016 these pollutants amounted to $94.2 \%$ of the level of 2007 , the target value being 82.6; concerning the indicator "the number of people living in areas with unfavorable ecological situation as a result of past economic and other activities, measured in thousands of people", the deviation was 261.9 thousand people. In fact, 17, 412.2 thousand people live on these territories, and according to the plan there should be $17,150.3$ thousand people, living on these territories [12].

The main reasons for not achieving the indicated values of the program's targets both the Ministry of Natural Resources and the analysts consider the reduction of financing of environmental activity from the state and business, as well as the critical situation with investments in fixed assets for environmental protection and rational use of natural resources. According to the last parameter, the investment level amounted to only $60.6 \%$ of the 2007 level, compared with $99.4 \%$ in 2015 and the planned value of $113.6 \%$ for 2016.

Not excluding the essential role of the financial side of environmental activity, it would be worthwhile drawing attention to the importance of the quality of legal support for this activity, which is largely provided, among other things, by fundamental scientific research in the field of environmental law. In this context, it is very disturbing that there is a lack of sufficient fundamental scientific research in the designated area (added and highlighted by the authors).

Over the past decade only five doctoral dissertations, in the opinion of the authors, can be attributed to fundamental research in the field of environmental law in Russia.

Gizatullin R.Kh. Ecological function of the state: theory and practice of implementation. The scientific novelty of the doctoral thesis is defined as the first comprehensive study of 
the ecological function of the state, conducted through the prism of simultaneous analysis of the role and practical activities of the President of the Russian Federation and the branches of state power, as well as analysis of environmental law measures used in the mechanism for ensuring rational using of nature, environmental protection and compliance with environmental rights and legitimate interests of Russian citizens. At the same time it is stated that the theoretical provisions, which have scientific novelty, have been formulated, and practical recommendations for improving the state's ecological function have been given [6];

Buchakova M.A. Coordination in the system of state and municipal management of environmental protection of the Russian Federation. The scientific novelty of the doctoral thesis is noted as the development of the concept of coordination, being an independent legal phenomenon, and as the determination of its significance in the system of state and municipal management of environmental protection. The author states that for the first time in national legal science, coordination is viewed as a complex fundamental problem. Attention is focused on the fact that the results of the research, represented by a combination of new theoretical and legal and methodological provisions, allow to solve the most significant problems arising in the sphere of legal relations under investigation. The author positions her research as an independent holistic concept, which opens up new opportunities and guidelines for further scientific research. It is emphasized that the cognitive approaches and methods used in the work are aimed primarily at improving the methodology of research and development work [7];

Vykhanova G.V. Legal problems of information support of using nature and environmental protection. The scientific novelty of the doctoral dissertation is the first complex monographic study of legal problems and the state of information support of using nature and environmental protection. The author of dissertation developed the theoretical, legal and regulatory framework of this field. It includes: the new category for the theory of ecological law "legal mechanism of information support of using nature and environmental protection" is substantiated, its components are considered: doctrinal, normative, regulatory, law enforcement and law protection. The definition of the legal concept of "environmental information" is given. New approaches to the assessment of the legal nature of environmental and information legal relations are suggested. Proposals have been made to improve legislation in the field of environmental information. Based on the system approach, an analysis of the information component of environmental and legal measures and ecological management was carried out, and proposals on their information support were formulated [8];

Vershilo N.D. Ecological law basis for sustainable development. The scientific novelty of the doctoral dissertation is in the fact that the conducted research can serve as a basis for further scientific and theoretical development of the provisions of the concept of sustainable development, as well as the mechanisms for its implementation. The proposals and recommendations formulated in the work can be used in law-making activities aimed at improving environmental and other legislation in the context of sustainable development. The dissertation research can be used in the process of teaching the academic discipline "environmental law" and training courses within the framework of sustainable development [9];

Misnik G.A. Compensation of environmental damage in Russian law.The scientific novelty of the doctoral thesis is its comprehensive study of existing legal forms of compensation for environmental harm from the perspective of expanding the bases of civil liability and strengthening the guarantees of its application. In the paper, the necessity of expanding the grounds for civil liability is justified. This can be achieved through the specification of the signs and criteria for assessing environmental damage, the application of channeled responsibility to all activities associated with the risk of causing large-scale environmental damage, establishing in the legislation an approximate list of sources of increased danger for which the judicial procedure for assessing signs of a source of increased danger is not applied. To strengthen the guarantees of compensation for environmental damage means to expand the list of presumptions used to prove the bases of civil liability, to specify the right to access to environmental information, to develop a unified model for assessing environmental risk as an element of environmental insurance [10].

\section{CONCLUSION}

The performed analysis allows noting the following.

First, in the conditions of non-linear global changes in the entire structure of modern society, the ambivalence of the main trends of globalization, the need for fundamental research of the new legal reality, of the specifics in the new conditions for solving environmental problems, their legal provision is growing.

Secondly, environmental law science in Russia is experiencing a clear deficit of fundamental research in this field.

Thirdly, most of the fundamental research already available remains as if "paralyzed" by the lack of a sufficient degree of approbation in practice, which significantly limits their relevance. This means that the understanding of law largely remains in the paradigm of the instrument, the means of power and its social engineering, which substantially restricts the practical significance of the available fundamental research in the field of environmental law science.

In this regard the authors consider it reasonable to create federal scientific centers for conducting and implementing fundamental scientific research on environmental law problems in the Russian Federation. To consider the possibility of their funding from the federal budget. To provide on the legislative level the mandatory testing of scientific research in practice (local level, the level of the subject of the Russian Federation, the federal level) with supporting documents. 


\section{REFERENCES}

[1] E.E.Grishnova. Some aspects of the development of politics and law in modern society // Socio-political sciences. - 2016. No. 4. P. 37-42.

[2] E.E.Grishnova. Law as a factor of politics // Business in the law. Economic and legal journal. - 2016. No. 8. P. 433-438.

[3] E.E.Grishnova. Dialectics of the interaction of politics and law in modern Russia // The security of Eurasia. - 2008. No. 1. P. 337-350.

[4] S.P.Zhdanov, N.V.Kuznetsova. On the issue of lobbying and lobbying activity // Bulletin of Kostroma State University named after N.A.Nekrasov. - 2016. No. 2. P. 273-276.

[5] B.V.Erofeev. Environmental Law of Russia: a textbook / B.V. Erofeev. - 22 th ed., Revised and expanded. - Moscow: Eksmo, 2011. - 528 p. - P. 10.

[6] R.Kh.Gizatullin. Ecological function of the state: theory and practice of implementation: the author's abstract of dis. ... dr. of law science (12.00.06) / R. Kh. Gizzatullin. - Moscow, 2014. - 56 p.

[7] M.A.Buchakova. Coordination in the system of state and municipal management of environmental protection of the Russian Federation: the author's abstract of dis. ... dr. of law science $(12.00 .06,12.00 .14)$ / M.A. Buchakova. - Moscow, 2011. - 36 p.

[8] G.V.Vypkhanova. Legal problems of information support of using nature and environmental protection: the author's abstract of dis. ... dr. of law science (12.00.06) / G.V. Vypkhanova. - Moscow, 2009. - 64 p.

[9] N.D.Vershilo. Ecological law basis for sustainable development: author's abstract of dis. ... dr. of law science (12.00.06) / N.D.Vershilo. - Moscow, 2008. - 54 p.

[10] G.A.Misnik. Compensation of environmental damage in Russian law: author's abstract of dis. ... dr. of law science (12.00.06) / G.A. Misnik. - Moscow, 2008. - 54 p.

[11] Overview of the macroeconomic situation. Ecological situation in Russia and abroad // Analytical series of ICSI, August 2017. [Electronic resource]. Access mode: https://icss.ru/economicheskaya v- rossii-mire. - 24.03.2018.

[12] Ministry of Natural Resources and Ecology of the Russian Federation. State report "On the condition and protection of the environment of the Russian Federation in 2016». 13 February, 2018. [Electronic resource]. Access mode: www.mnr.gov.ru. 